\title{
Origin of high fluoride in groundwater of the Tuticorin district, Tamil Nadu, India
}

\author{
C. Singaraja ${ }^{1}$-S. Chidambaram ${ }^{2} \cdot$ Noble Jacob $^{3}$-G. Johnson Babu ${ }^{1} \cdot$ S. Selvam ${ }^{4} \cdot$ P. Anandhan ${ }^{2}$ - E. Rajeevkumar ${ }^{1}$. \\ K. Balamurugan ${ }^{1} \cdot$ K. Tamizharasan ${ }^{1}$
}

Received: 18 July 2016 / Accepted: 26 March 2018 / Published online: 2 April 2018

(c) The Author(s) 2018

\begin{abstract}
This paper reports the results of higher $\mathrm{F}^{-}$and $\mathrm{HCO}_{3}^{-}$concentrations and its response to high $\mathrm{pH}$ level in a hard rock terrain in Tamil Nadu, India. About 400 groundwater samples from the study area were collected from a period of four different seasons and analysed for $\mathrm{F}^{-}, \mathrm{HCO}_{3}^{-}$and other major cations and anions. The key rationale for the higher fluoride and bicarbonate in the study area is the soaring rate of the leaching fluoride-bearing minerals and weathering processes. Fluoride and $\mathrm{HCO}_{3}^{-}$ ranges from BDL to $3.30 \mathrm{mgl}^{-1}$ and 12 to $940 \mathrm{mgl}^{-1}$, its concentrations are lower for the period of SWM and it increases during POM and reaches to a maximum in PRM. Higher dissolution is observed in the NEM season due to rainfall impact. Spatial distribution and factor score show that the higher concentrations of $\mathrm{F}^{-}$and $\mathrm{HCO}_{3}^{-}$are eminent in the northern and central zone of the study area due to the impact of lithology. The higher values in $\mathrm{pCO}_{2}$ versus $\mathrm{HCO}_{3}^{-}$plot indicate higher residence time which favours more water-rock interactions, which further increase the $\mathrm{F}^{-}$concentrations in groundwater. $\mathrm{HCO}_{3}^{-}$is linearly correlated with $\mathrm{F}^{-}$which indicates that these ions were consequent from the weathering influences. At the same time, poor correlation of $\mathrm{F}^{-}$with $\mathrm{pH}$ could possibly be due to the increase of alkalinity follow-on from the swell of bicarbonate level with very low $\mathrm{Ca}^{2+}$ that promotes increase in $\mathrm{F}^{-}$concentration in the groundwater.
\end{abstract}

Keywords Fluoride $\cdot$ Bicarbonate $\cdot$ Water-rock interactions $\cdot$ Weathering processes $\cdot$ Lithology $\cdot$ India

\section{Introduction}

Growing groundwater contamination causes not only the deterioration of water quality but also make threats to human health, the stability of aquatic ecosystems, economic improvement and social wealth. The cause for the

C. Singaraja

geolionking@gmail.com

S. Chidambaram

chidambaram_s@rediffmail.com

Noble Jacob

noblej@barc.gov.in

G. Johnson Babu

geojohn22@gmail.com

S. Selvam

geoselvam10@gmail.com

P. Anandhan

vijayanand_pa@yahoo.co.in

E. Rajeevkumar

rajeevmanan95@gmail.com poor quality of groundwater is attributable to variety of reasons including interaction between water, soluble minerals, salts, and anthropogenic pollution (Codling et al. 2014; Subba Rao et al. 2016). Despite the intricate hydro and biogeochemical issues, the quantity of fresh ground water is limited. Besides the major components in water

K. Balamurugan

arubalamurugan95@gmail.com

K. Tamizharasan

sharongeotech@gmail.com

1 Department of Geology, Presidency College (Autonomous), Chennai, Tamil Nadu 600005, India

2 Department of Earth Sciences, Annamalai University, Annamalai Nagar, Tamil Nadu 608002, India

3 Isotope and Radiation Application Division, Bhabha Atomic Research Centre, Mumbai 400 085, India

4 Department of Geology, V.O. Chidambaram College, Thoothukudi, Tamil Nadu 628 008, India 


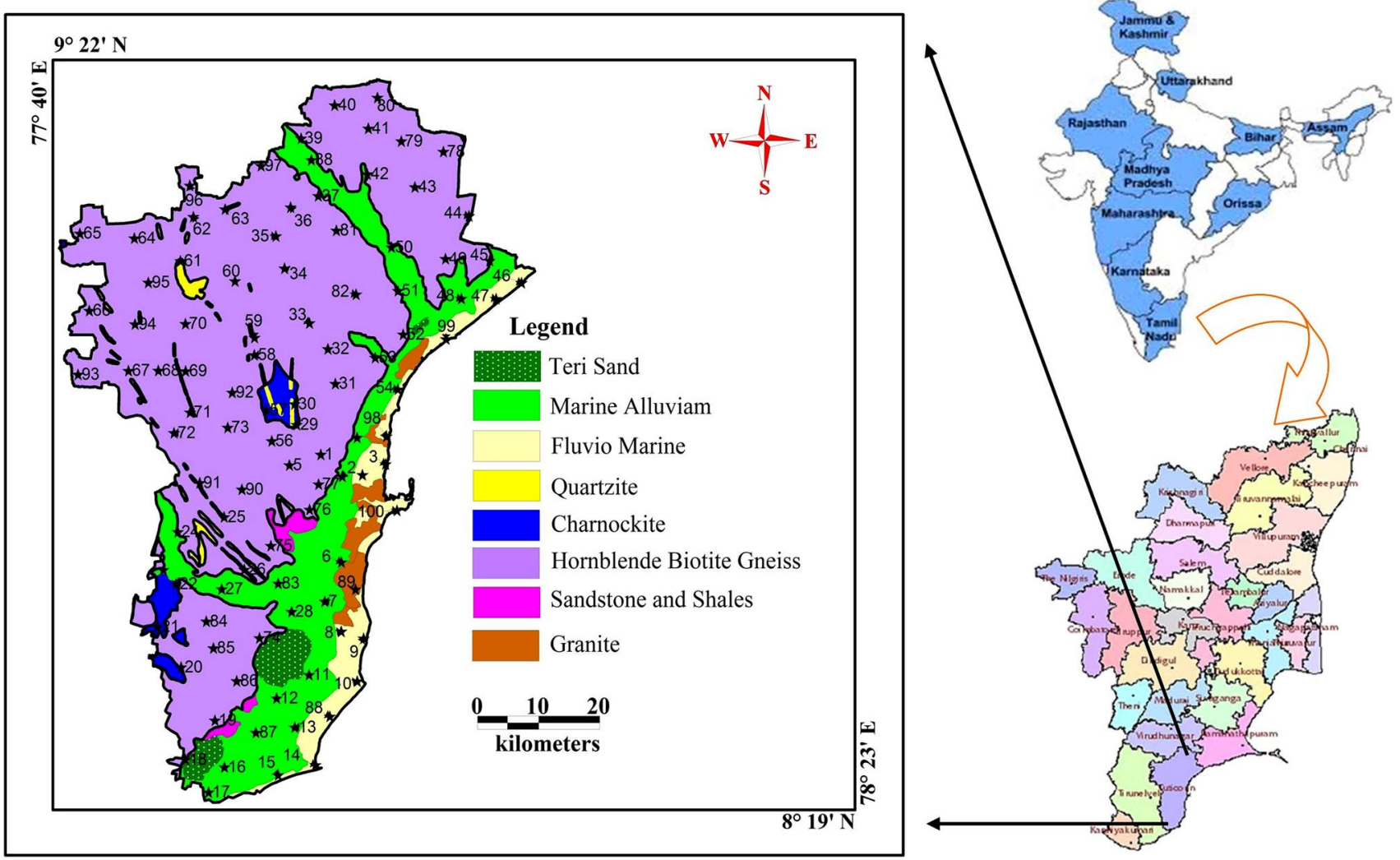

Fig. 1 Location and geology map of the study area

namely $\mathrm{Na}^{+}, \mathrm{Mg}^{2+}, \mathrm{Ca}^{2+}, \mathrm{SO}_{4}^{2-}, \mathrm{HCO}_{3}^{-}$, and $\mathrm{Cl}^{-}$, the secondary components include $\mathrm{F}^{-}, \mathrm{K}^{+}, \mathrm{PO}_{4}^{3-}, \mathrm{NO}_{3}^{-}$and $\mathrm{CO}_{3}^{2-}$ (Chidambaram et al. 2013). Fluoride and bicarbonate becomes toxic if it occurs in drinking water, and the maximum acceptable limit of $\mathrm{F}^{-}$and $\mathrm{HCO}_{3}^{-}$are 1.5 and 125 to $350 \mathrm{mgl}^{-1}$, respectively, as per WHO standards (2004). Fluorine has unenthusiastic effects on human health when its intake levels are either too high or too low. High fluoride level can cause negative effects on human health, such as dental fluorosis, skeletal fluorosis, impaired thyroid function, and lower intelligence in children (Edmunds and Smedley 2013). Alkalinity in natural groundwater is mainly derived from the dissolution of carbonate minerals and $\mathrm{CO}_{2}$ present in the atmosphere and in the soil above the water table (Gao et al. 2016a, b). The fluoride in groundwater shows variation with respect to the lithounits of the study area. High concentration of $\mathrm{F}^{-}$is seen in groundwater from hard rock, fluvial as well as alluvial aquifers, which might be derived from minerals such as micas, apatite, fluorite, soil dust, chemical stimulant, clay and shale (Naseem et al. 2010; Manikandan et al. 2014; Li et al. 2015). Hence, fluoride problems are predisposed to arise in hard rock and sedimentary aquifer where these minerals are rich in the country rocks.
Generally, fluoride show negative correlations with calcium and magnesium concentrations and positive correlation with bicarbonate concentrations in groundwater (Chae et al. 2006; Gao et al. 2011; Subba Rao et al. 2016). Higher levels of dissolved fluoride are usually related with high $\mathrm{pH}$ and $\mathrm{Na}^{+}-\mathrm{HCO}_{3}^{-}$type waters, while the temperature and depth of groundwater can also play vital roles (Chae et al. 2007). Ion exchange has been found to influence fluoride levels through both base exchange, which reduces calcium concentrations (Edmunds and Smedley 2005; Chae et al. 2006) and anion exchange, in which $\mathrm{OH}^{-}$in groundwater replaces $\mathrm{F}^{-}$on certain clay minerals or weathered micas (Guo et al. 2007). Thermodynamics computation indicated that some of this high fluoride groundwater is supersaturated with respect to fluorite, fluorapatite and hydroxyl-apatite (Singaraja et al. 2012; Chidambaram et al. 2012; Li et al. 2015). The overuse of fertiliser on the soil for agricultural activities would also be the possible source for the high fluoride and bicarbonate content in groundwater (Singaraja et al. 2012; Gao et al. 2016a, b). It is also implicit that the similar lithology from the nearby district and furthermore hard rock terrains are usually reported to have high concentrations of fluoride and bicarbonate in groundwater (Chidambaram et al. 2012; Manikandan et al. 2014). In addition, higher concentrations of $\mathrm{F}^{-}$and $\mathrm{HCO}_{3}^{-}$could possibly come from hornblende biotite 


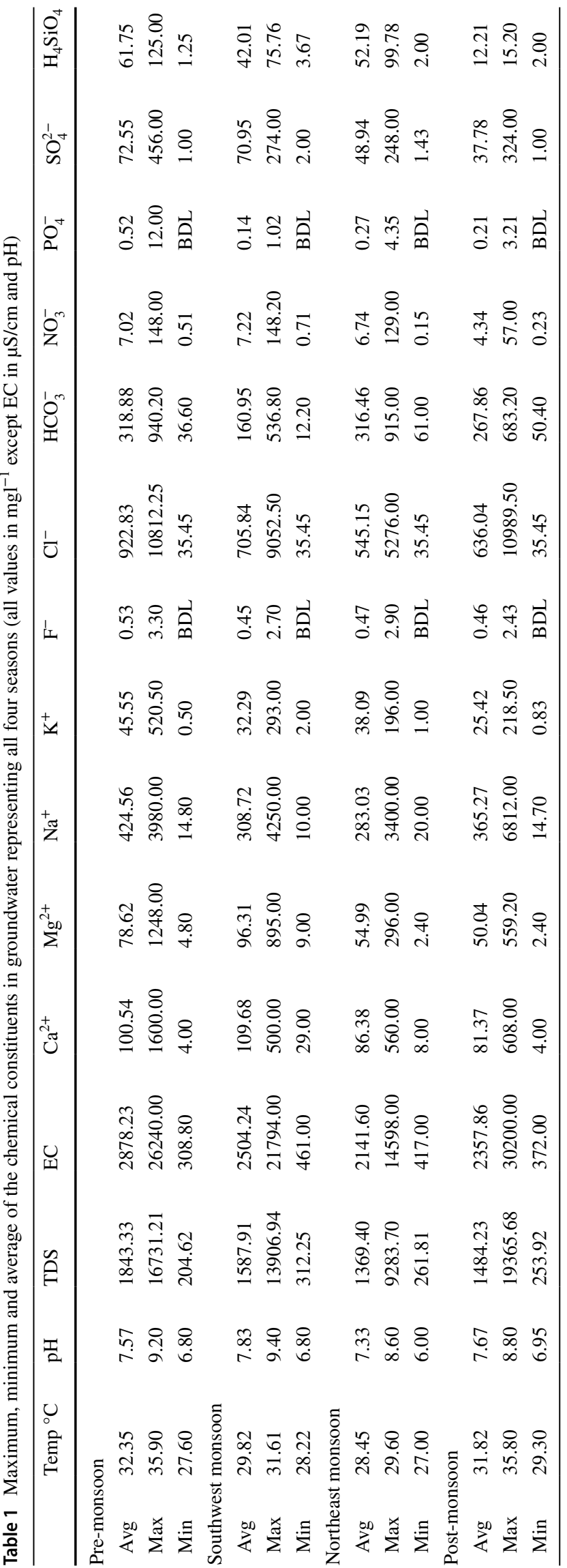

gneiss (HBG) and charnockites subjected to weathering in hard rock terrain (Singaraja et al. 2012; Manivannan et al. 2010; Subba Rao et al. 2016).

In India, several states face problems due to the high $\mathrm{F}^{-}$and $\mathrm{HCO}_{3}^{-}$content in groundwater. It is well-known that $\mathrm{F}^{-}$and $\mathrm{HCO}_{3}^{-}$contaminations are present in the groundwater in the various districts of Tamil Nadu State, India. Tuticorin district in Tamil Nadu is one such big area where high concentrations of fluoride and bicarbonate are present in groundwater. However, no major studies have been conducted till date in this area. In the present study, an attempt is made to correlate the chemical ions and geological sequence to identify the origin and geochemical processes prevailing in high fluoride and bicarbonate groundwater in Tuticorin district of Tamil Nadu. Another objective of the study is to understand the spatial variations and saturation index of fluoride and bicarbonate minerals in groundwater.
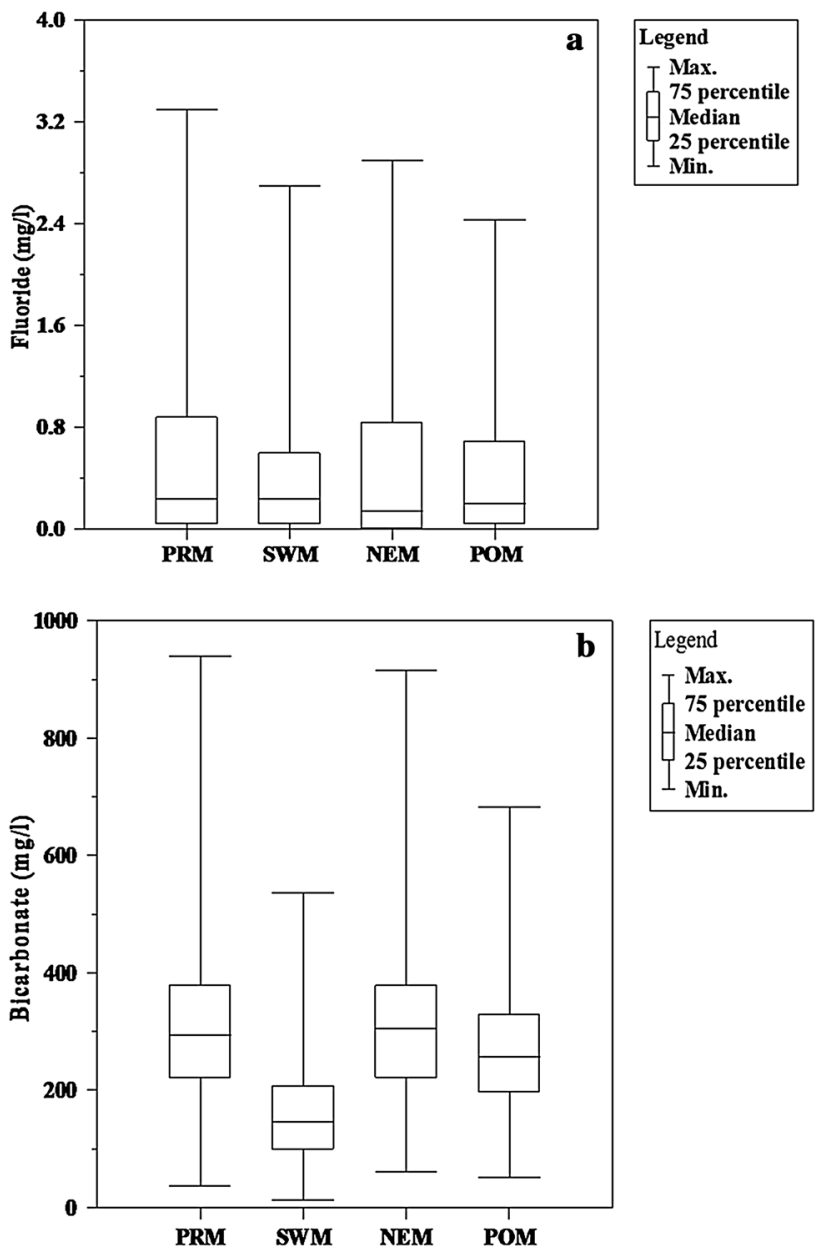

Fig. 2 Box plot for the maximum, minimum, and average of the chemical constituents in groundwater during PRM and POM (all values in $\mathrm{mg} \mathrm{l}^{-1}$ except $\mathrm{pH}$ ) 

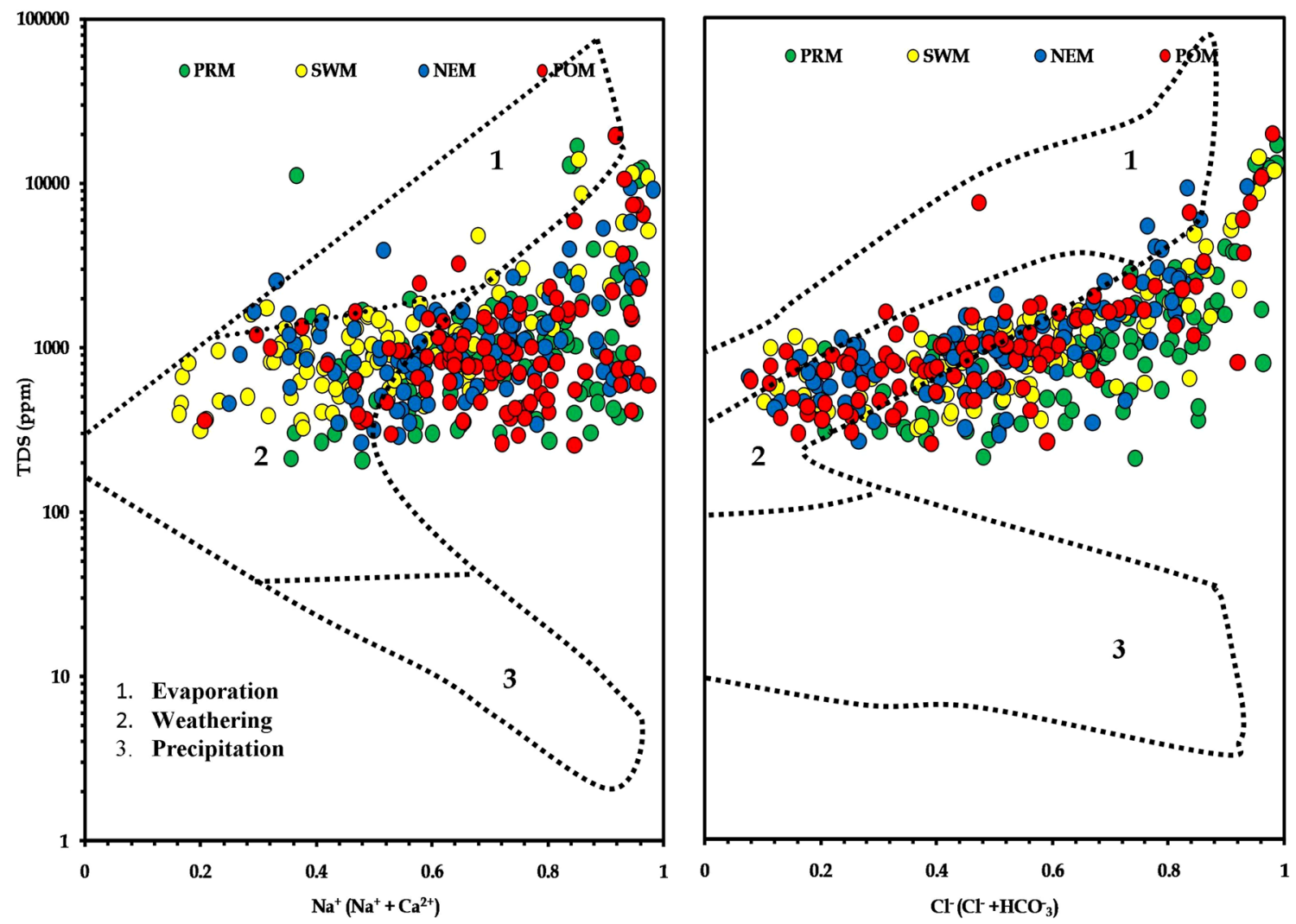

Fig. 3 Major ion chemistry showing nature of water (fields after Gibbs 1970)

\section{Description of study area}

The study area, lying between latitude $8^{\circ} 19^{\prime}$ to $9^{\circ} 22^{\prime} \mathrm{N}$ and longitude $77^{\circ} 40^{\prime}$ to $78^{\circ} 23^{\prime} \mathrm{E}$ with a total area of $4620 \mathrm{Km}^{2}$ (Fig. 1) is situated in southeast part of Tamil Nadu, India. Geologically, five most important lithounits are present in this area, hornblende biotite gneiss, charnockite, quartzite, granite, and alluvial and fluvial plains (Fig. 1). The sandstone and teri sands form small patches in the study area. Three major rivers such as Tambraparani, Vaiparand and Karamanaiyar are draining within the study area. The area experiences a tropical climate with a yearly rainfall that ranges between 570 and $740 \mathrm{~mm}$ (CGWB 2009). The V.O. Chidambaram port and hurriedly rising industrial region consisting of major and small-scale industries (SIPCOT) are developing in the fluvial region of the study area (Singaraja et al. 2012).

\section{Materials and method}

\section{Sample collection and analysis}

A total of about 400 groundwater samples were collected covering most of the geological formations representing the entire district during pre-monsoon (PRM), southwest monsoon (SWM), northeast monsoon (NEM) and post-monsoon (POM). The physico-chemical parameters like $\mathrm{pH}$, electrical conductivity (EC), temperature of groundwater were measured in situ using hand-held instruments (Eutech make). The $\mathrm{F}^{-}$was analysed using the Orion Ion selective electrodes and $\mathrm{HCO}_{3}^{-}$by titration method; $\mathrm{Cl}^{-}, \mathrm{SO}_{4}^{2-}, \mathrm{PO}_{4}^{-}, \mathrm{NO}_{3}^{-}, \mathrm{H}_{4} \mathrm{SiO}_{4}$, $\mathrm{Ca}^{2+}, \mathrm{Mg}^{2+}, \mathrm{Na}^{+}$and $\mathrm{K}^{+}$were analysed using the ion chromatograph (IC, Metrohm 861). The accuracy of analysis of major ions was checked by error percentage computation and it was found to be less than $10 \%$ (Hem, 1985). In this study, saturation indices (SI) of fluoride and carbonate minerals were calculated by WATEQ4F (Hammarstrom et al. 2005) software. The correlation and factor analyses were computed using Statistical Package of Social Studies (SPSS) version 17 and spatial diagram were constructed using Arc GIS software.

\section{Results and discussion}

The maximum, minimum, and average values of various chemical constituents in the groundwater samples collected from the study area is shown in Table 1. 
The ascending order of cations and anions concentrations areas follows: $\mathrm{Na}^{+}>\mathrm{Ca}^{2+}>\mathrm{Mg}^{2+}>\mathrm{K}^{+}$and $\mathrm{Cl}^{-}>\mathrm{HCO}_{3}^{-}>\mathrm{SO}_{4}^{2-}>\mathrm{H}_{4} \mathrm{SiO}_{4}>\mathrm{NO}_{3}{ }^{-}>\mathrm{F}^{-}>\mathrm{PO}_{4}^{3-}$ during all the seasons. The $\mathrm{pH}$ ranges from 6 to 9.40 indicating that the groundwater is changing from slightly acidic to alkaline nature. The lowest $\mathrm{pH}$ is observed in NEM but highest in PRM. EC ranges from 310 to $30,200 \mu \mathrm{S} / \mathrm{cm}$ in the study area. In all seasons, higher electrical conductivities were noted along the coastal region which was possibly due to seawater intrusion (Singaraja et al. 2012). TDS in the groundwater samples varies between 205 and $19,370 \mathrm{mgl}^{-1}$ and higher concentrations are found during PRM followed by SWM, POM and NEM. Water temperatures have a wide distribution in all the seasons which ranges from 28 to $36^{\circ} \mathrm{C}$.

The $\mathrm{Ca}^{2+}$ concentration in the groundwater ranges from 4 to $1600 \mathrm{mgl}^{-1}$. It is higher in SWM and lower during POM. The $\mathrm{Ca}^{2+}$ may be derived from calcite, hornblende and plagioclase minerals. $\mathrm{Mg}^{2+}$ concentration ranges from 2.4 to $1248 \mathrm{mgl}^{-1}$ in the groundwater samples of the study area. Relatively higher concentration of $\mathrm{Mg}^{2+}$ is observed in the SWM season and lesser during POM season. Higher levels of $\mathrm{Mg}^{2+}$ in groundwater is seen in $\mathrm{HBG}$ and charnockite region located along the western part of the study area that have $\mathrm{Mg}^{2+}$ affluent pyroxene as the predominant mineral (Chidambaram et al. 2012). Also, the higher level of $\mathrm{Mg}^{2+}$ seen along the coastal zone perhaps may be because of the influence of seawater intrusion (Subba Rao et al. 2012; Singaraja et al. 2014). $\mathrm{Na}^{+}$concentration ranges from 10 to $6212 \mathrm{mgl}^{-1}$ which is higher in the PRM and lesser in NEM. The main sources of $\mathrm{Na}^{+}$in groundwater are hornblende biotite gneiss, charnockite, plagioclase feldspar rock types seen along the western part of the region (Srinivasamoorthy et al. 2009; Thivya et al. 2013; Venkatramanan et al. 2013) as well as seawater intrusion along the coastal region (Thilagavathi et al. 2014). $\mathrm{K}^{+}$concentration ranges between 0.5 and $520 \mathrm{mgl}^{-1}$ with higher values observed in POM. At a few locations, abnormalities are seen irrespective of seasons possibly due to weathering and urban landfill leaching (Thivya et al. 2015; Selvam et al. 2016).

$\mathrm{Cl}^{-}$is the leading ion among anions during all the seasons, and its higher values are noted in the coastal zone, may be because of seawater intrusion (Srinivasamoorthy et al. 2008; Chidambaram et al. 2013). Its concentration ranges from 35.5 to $10,990 \mathrm{mgl}^{-1}$; higher values are prominent in PRM groundwater samples. $\mathrm{SO}_{4}^{2-}$ concentration ranges from 1 to $456 \mathrm{mgl}^{-1}$, and the highest concentration is observed in PRM and lesser in POM. Higher concentrations of $\mathrm{SO}_{4}^{2-}$ mainly derived from evaporate minerals such as gypsum and anhydrite, which are sulphates of magnesium and sodium. It would also possibly migrate to groundwater from salt pan activities happening along the eastern part of the study area (Chandrasekharan et al. 1997). Nitrate ranges from 0.2 to $148 \mathrm{mgl}^{-1}$, which is noted to be higher in PRM. The concentration of silica $\left(\mathrm{H}_{4} \mathrm{SiO}_{4}\right)$ ranges from 1.2 to $125 \mathrm{mgl}^{-1}$, higher values are observed during PRM compared to other seasons. Higher concentration of $\mathrm{H}_{4} \mathrm{SiO}_{4}$ in groundwater is chiefly attributable to the weathering of silicate minerals (Prasanna et al. 2010). $\mathrm{PO}_{4}^{3-}$ concentration ranges from $\mathrm{BDL}$ to $12 \mathrm{mgl}^{-1}$; higher values are seen during PRM. $\mathrm{SO}_{4}^{2-}$ and $\mathrm{PO}_{4}^{3-}$ in the groundwater may also arise from the use of fertilisers. In addition, it can also come from apatite mineral found in HBG and charnockite (Brindha et al. 2012; Chidambaram et al. 2012). One of the reasons for the high bicarbonate in the study area is the high rate of the dissociation of $\mathrm{H}_{2} \mathrm{CO}_{3}$ (Rafique et al. 2015). $\mathrm{HCO}_{3}^{-}$concentration ranges from 1 to $940 \mathrm{mgl}^{-1}$, with higher values in PRM samples followed by NEM, POM and SWM. It is attributed to carbonate chemical weathering process (Mondal and Singh 2004; Li et al. 2015). It is also noted that the higher values of $\mathrm{HCO}_{3}^{-}$in the groundwater controls the mineral dissolution processes (Thivya et al. 2015). Fluoride concentration ranges from BDL to $3.3 \mathrm{mgl}^{-1}$, with higher values in PRM season followed by NEM, POM and SWM. Hornblende biotite gneiss is one of the most important sources
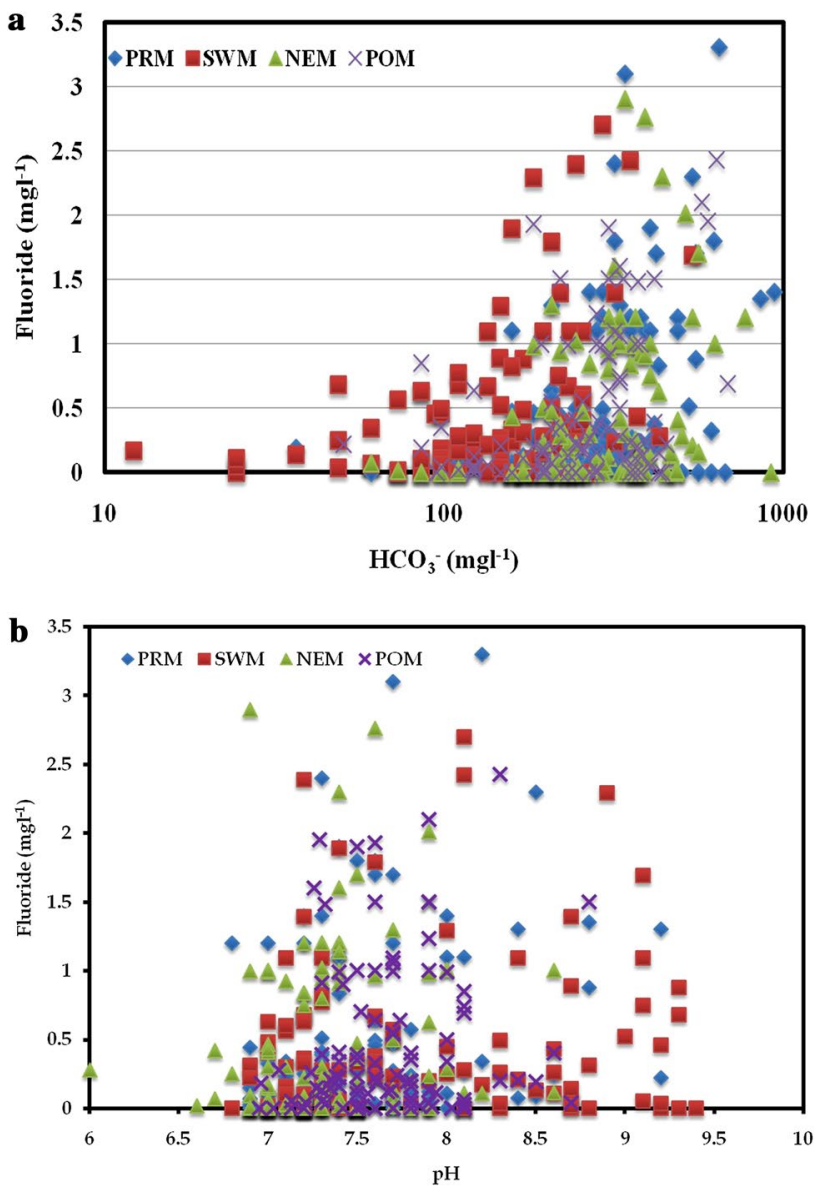

Fig. 4 a Variation of $\mathrm{F}^{-}$concentrations with $\mathrm{HCO}_{3}^{-}$and $\mathbf{b} \mathrm{F}^{-}$concentrations with $\mathrm{pH}$ in groundwater samples from Tuticorin district

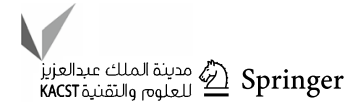



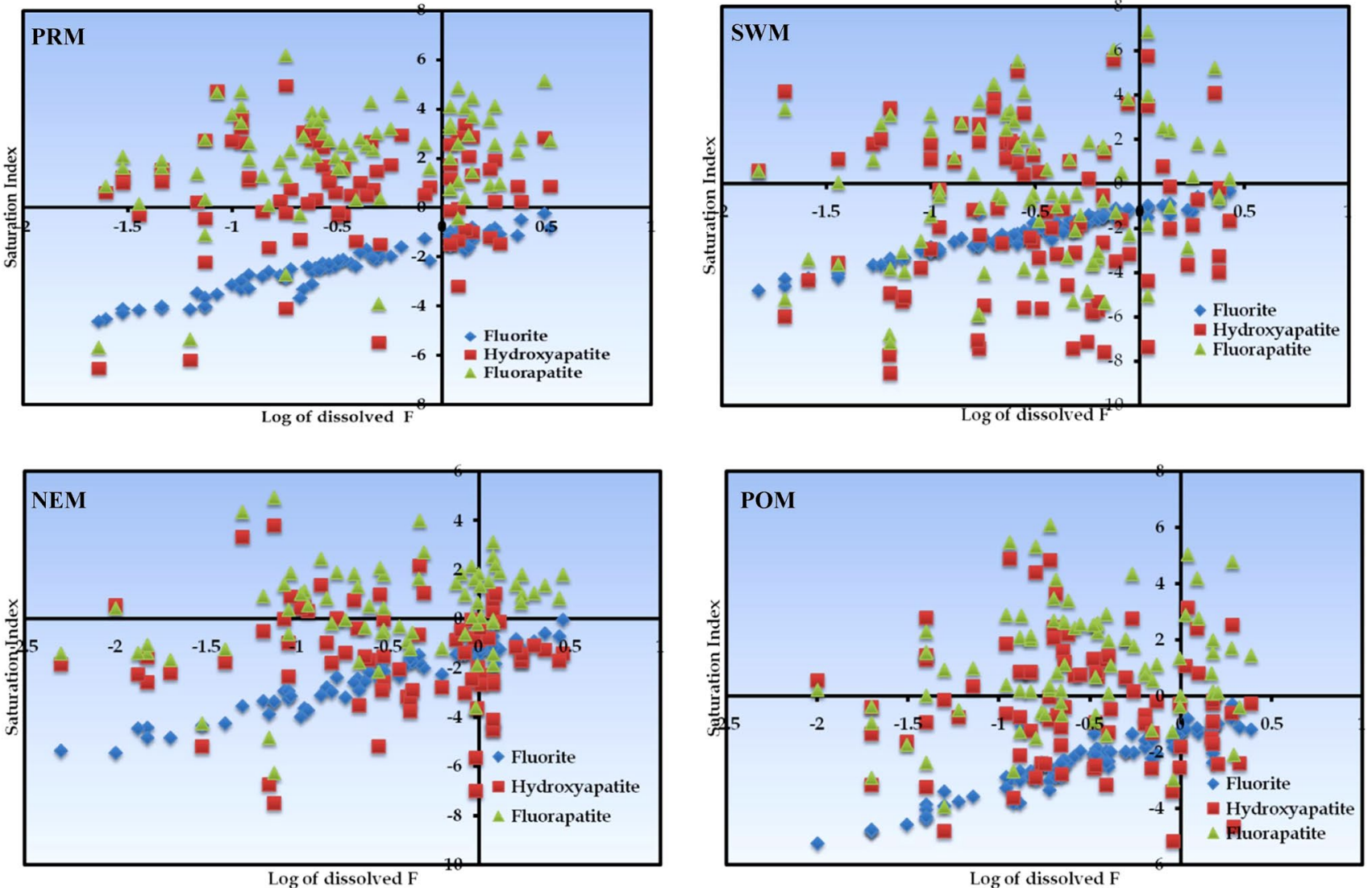

Fig. 5 Variation of saturation index of different fluoride minerals with dissolved $\mathrm{F}^{-}$for samples representing different seasons

of $\mathrm{F}^{-}$in the groundwater (Chidambaram et al. 2013). The lithological influences in the dissolution of fluoride ions in groundwater are studied by Manikandan et al. (2014). The higher concentrations of fluoride in groundwater could be due to the weathering as well as leaching of biotite, hornblende, apatite and mica minerals (Srinivasamoorthy et al. 2008; Chidambaram et al. 2013). The seasonal variation of fluoride and bicarbonate is shown in Fig. 2. It is seen that most of the samples fall above the median value during PRM, NEM and POM, but there is not much variation during SWM. Fluoride concentration beyond the WHO drinking water limit is observed during PRM (9\%), SWM (7\%) and NEM and POM (6\%). In the case of bicarbonate, majority of the samples are above the WHO permissible limit like PRM (33\%), SWM (4\%), NEM (37\%) and POM (22\%). For inferring the dominant controls on water quality, the data are plotted on Gibbs diagrams (Gibbs1970) (Fig. 3). These plots suggest that groundwater in the study area is closely influenced by weathering, although some samples appear to reflect only the influence of evaporation. This finding suggests that the groundwater chemistry is largely controlled by weathering and precipitation of lower solubility minerals, as evaporation causes salinity to increase.

\section{The origin of high fluoride in groundwater}

In all seasons, $\mathrm{F}^{-}$is found to be positively correlated with $\mathrm{HCO}_{3}^{-}$with significant correlation coefficient (Fig. 4). Maximum values are observed in PRM. Figure 4 shows that high concentration of $\mathrm{F}^{-}$are observed in both low and high $\mathrm{pH}$ conditions that may be attributed to weathering of biotite minerals from HBG. In addition, alkaline $\mathrm{pH}$ conditions are favourable for the dissolution of $\mathrm{F}^{-}$into groundwater (Chidambaram et al. 2012; Subba Rao et al. 2012; Singaraja et al. 2014). At lower $\mathrm{pH}$ conditions, groundwater containing dissolved $\mathrm{HCO}_{3}^{-}$in the form of $\mathrm{H}_{2} \mathrm{CO}_{3}$ reacts with the minerals and releases $\mathrm{H}^{+}, \mathrm{F}^{-}$, cations and $\mathrm{HCO}_{3}^{-}$, according to the equation given below.

$$
\begin{aligned}
& (\mathrm{Na})_{2}(\mathrm{Ca}, \mathrm{Mg}, \mathrm{Fe})_{3} \mathrm{Al}_{2} \mathrm{Si}_{6} \mathrm{O}_{20}(\mathrm{OH})_{4} \\
& \quad+\mathrm{H}_{2} \mathrm{O}+\mathrm{H}_{2} \mathrm{CO}_{3} \\
& \quad \rightarrow\left(\mathrm{Ca}, \mathrm{Mg}_{3} \mathrm{Fe}_{3}\right) \mathrm{Al}_{3} \mathrm{Si}_{5} \mathrm{O}_{20}(\mathrm{OH}) \\
& +\mathrm{F}^{-}+\mathrm{Na}^{+}+\mathrm{H}^{+}+\mathrm{HCO}_{3}^{-}
\end{aligned}
$$

At higher $\mathrm{pH}$ conditions, hydrolysis takes place which releases $(\mathrm{OH})^{-}$along with cations and fluoride according to the equation given below. 

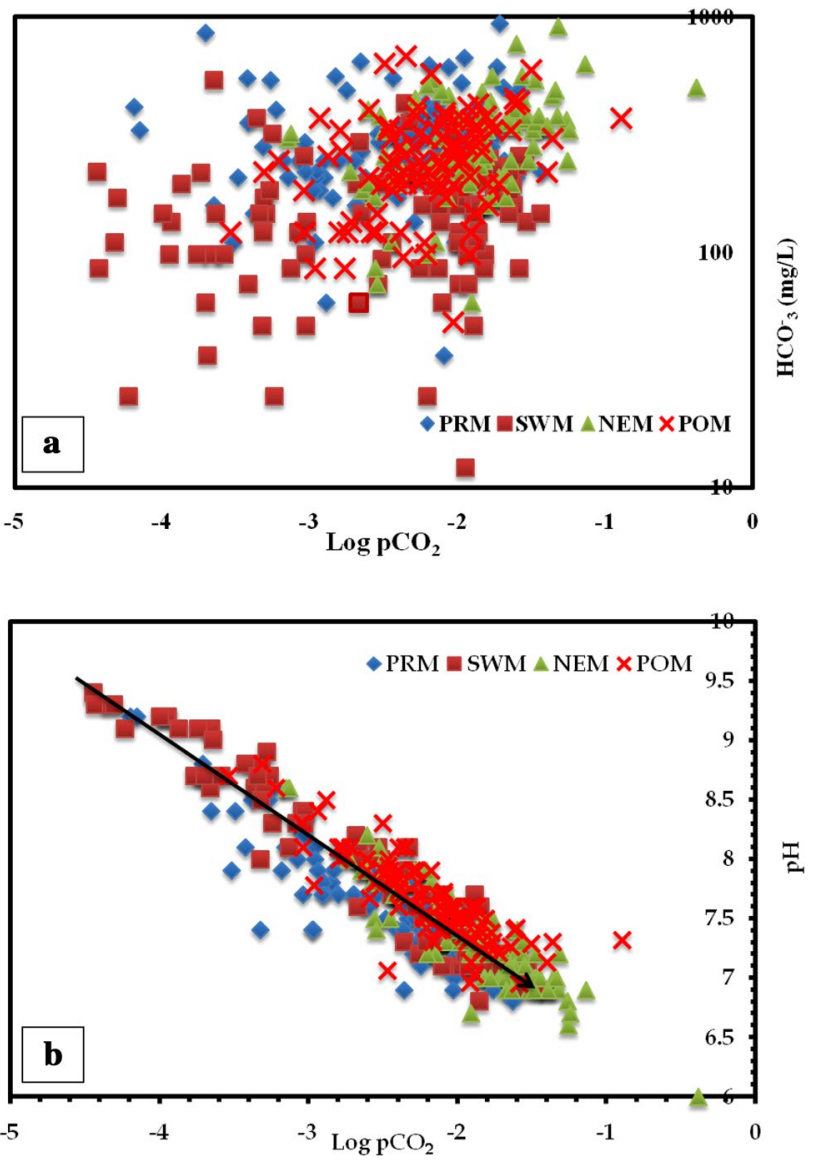

Fig. 6 a $\log \mathrm{pCO}_{2}$ versus $\mathrm{HCO}_{3}^{-}$and $\mathbf{b} \log \mathrm{pCO}_{2}$ versus $\mathrm{pH}$ relationship of groundwater samples for different seasons

$$
\begin{aligned}
& (\mathrm{Na})_{2}(\mathrm{Ca}, \mathrm{Mg}, \mathrm{Fe})_{3} \mathrm{Al}_{2} \mathrm{Si}_{6} \mathrm{O}_{20}(\mathrm{OH})_{4}+\mathrm{H}_{2} \mathrm{O} \\
& \quad \rightarrow\left(\mathrm{Mg}_{3} \mathrm{Fe}_{3}\right) \mathrm{Al}_{3} \mathrm{Si}_{5} \mathrm{O}_{20}(\mathrm{OH}) \\
& +\mathrm{OH}^{-}+\mathrm{F}^{-}+\mathrm{Na}^{+}+\mathrm{Ca}^{2+}+\mathrm{Mg}^{2+}+\mathrm{HCO}_{3}^{-}
\end{aligned}
$$

These equations indicate that elevated $\mathrm{HCO}_{3}^{-}$contents favour $\mathrm{F}^{-}$release from the hard rock aquifer matrix into the groundwater. The HBG and charnockites present in the study area contains mica, quartz, calcite and feldspar. The $\mathrm{F}^{-}$present in the mineral will be desorbed into the groundwater, when the $\mathrm{HCO}_{3}^{-}$concentrations are high because of $\mathrm{HCO}_{3}^{-}$which is a strong competitor for sorption (Gao et al. 2011). In few samples at high $\mathrm{pH}, \mathrm{OH}^{-}$could release $\mathrm{F}^{-}$ions and result in the sorption of $\mathrm{F}^{-}$into the aquifers (Jacks et al. 2005). The release of high concentration of fluoride into groundwater at higher $\mathrm{pH}$ ranges may also be due to anthropogenic sources.

Generally, it is seen that the $\mathrm{HCO}_{3}^{-}$and $\mathrm{F}^{-}$concentrations are lesser during SWM and it increases during POM and reaches to a maximum in PRM and then they get diluted during NEM (Fig. 4). This leads to the interpretation that

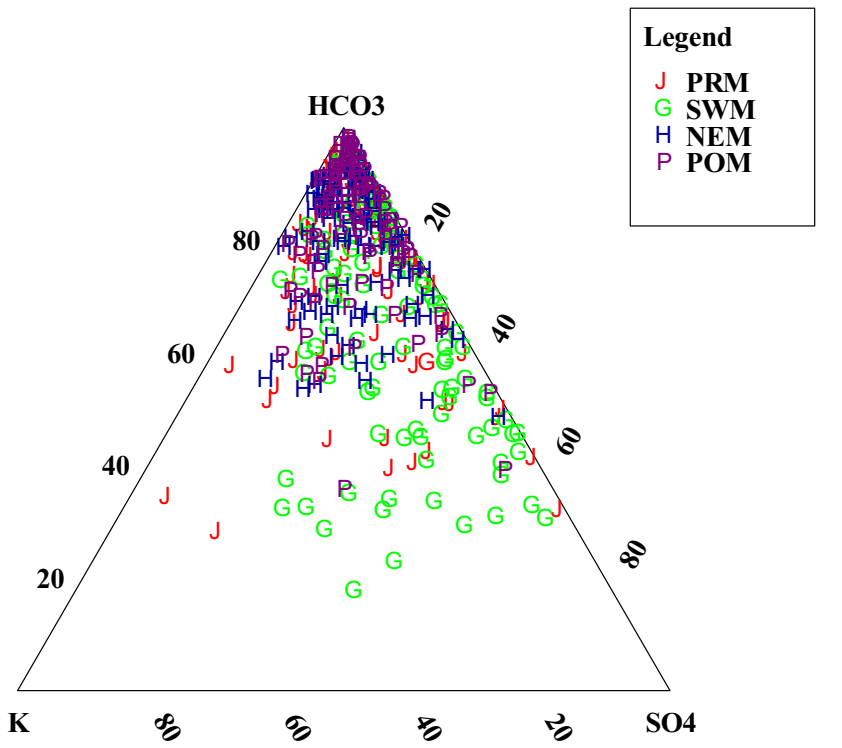

Fig. 7 Relative $\mathrm{HCO}_{3}^{-}, \mathrm{K}^{+}$and $\mathrm{SO}_{4}^{2-}$ contents of waters of the study area

higher dissolution and dispersivity of $\mathrm{F}^{-}$is observed in the NEM season due to the impact of rainfall.

\section{Fluoride-bearing minerals}

The association of $\mathrm{F}^{-}$ion to the saturation index (SI) of different $\mathrm{F}^{-}$bearing minerals like fluorite $\left[\mathrm{CaF}_{2}\right]$, fluorapatite $\left[\mathrm{Ca}_{5}\left(\mathrm{PO}_{4}\right)_{3}(\mathrm{OH})\right]$ and hydroxyl-apatite $\left[\mathrm{Ca}_{5}\left(\mathrm{PO}_{4}\right)_{3} \mathrm{~F}\right]$ are studied. The calculated saturation indices (SI) values for fluorite minerals and $\log$ of dissolved concentration of fluoride are shown in Fig. 5. Most of the groundwater samples were saturated or over-saturated with respect to the dissolved concentration of fluoride. Initially, SI increases simultaneously with the $\mathrm{F}^{-}$concentration, until $\mathrm{F}^{-}$concentration reached a value of 6 due to long residence time of water-rock interaction which lead to the release of $\mathrm{F}^{-}$from fluorine-bearing minerals (Rafique et al. 2015; Li et al. 2015). Saturations show fluorapatite dominance followed by hydroxyl-apatite and fluorite. $\mathrm{F}^{-}$when released into the system, it readily adsorbs on to the apatite and makes it fluorapatite, later the $(\mathrm{OH})^{-}$in the hydroxyl-apatite are preferred by $\mathrm{F}^{-}$and at the end, a separate compound namely fluorite is formed. There is a clear linear relationship between $\mathrm{F}^{-}$concentration and SI of fluorite irrespective of the seasons (Edmunds and Smedley 2005; Rafique et al. 2015).

\section{Relationship between $\mathrm{pCO}_{2}$ and $\mathrm{HCO}_{3}^{-}$}

The $\mathrm{pCO}_{2}$ values in the groundwater ranges from -4.19 to -1.43 during PRM, -4.43 to -1.43 during SWM,-3.14 to 

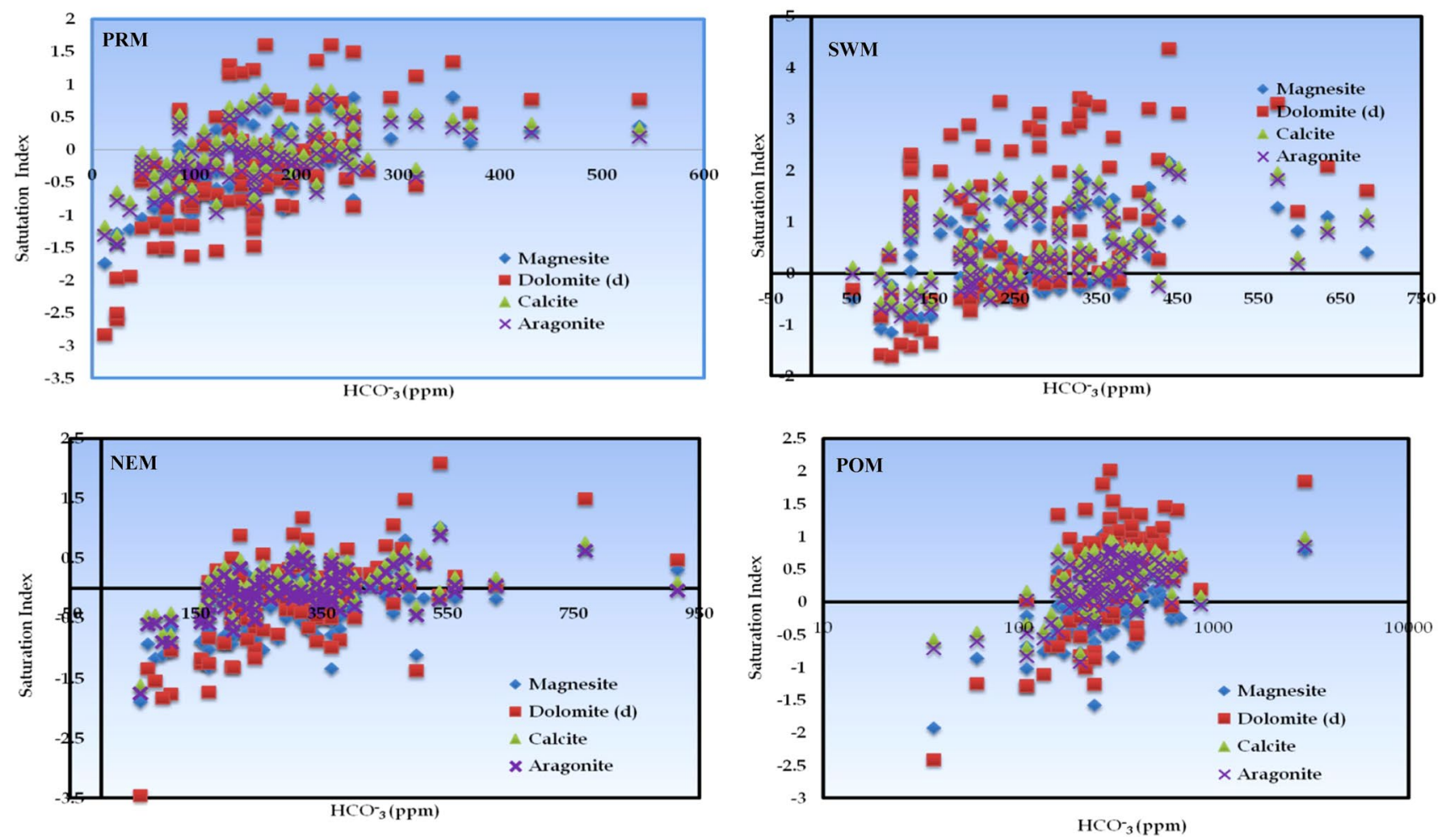

Fig. 8 Variation of saturation index of different carbonate minerals with $\mathrm{HCO}_{3}$ for samples collected during different seasons

-0.38 and -3.53 to -0.89 during NEM and POM seasons, respectively, indicating an increase in $\mathrm{pCO}_{2}$ with increase in bicarbonate (Fig. 6). The increase is found in all the groundwater samples irrespective of season. The higher values of $\mathrm{pCO}_{2}$ also indicate longer residence times (Prasanna et al. 2010). Water with a high $\mathrm{pCO}_{2}$ of around -2 indicates deep circulation of groundwater with a lesser amount of atmospheric contact or higher saturation of carbonate minerals. This results from the interaction of minerals present in the rocks through which it flows (Ayoob and Gupta 2006; Chidambaram et al. 2012). It is also evident that $\log \mathrm{pCO}_{2}$ values linearly decreases with $\mathrm{pH}$ indicating fresh water recharge or less atmospheric interaction with the system (Chidambaram et al. 2013). The higher values of $\log \mathrm{pCO}_{2}$ coincide with the lesser values of $\mathrm{pH}$ indicating rock-water interactions. The $\mathrm{pH}$ increases from 6 to 9.4 (Fig. 6), this progressive increase of $\mathrm{H}^{+}$concentration and $\log \mathrm{pCO}_{2}$ values indicate less interaction of the groundwater system with the atmosphere. The ion exchange reactions occur by the exchange of $\mathrm{H}^{+}$ions in the host rock. In all seasons, the groundwater remains as $\mathrm{HCO}_{3}^{-}$type. From the Fig. 7, it is clear that there is a shift from $\mathrm{Na}^{+}+\mathrm{K}^{+}$to $\mathrm{Ca}^{2+}$ and $\mathrm{Cl}^{-}$to $\mathrm{HCO}_{3}^{-}$type (Manivannan et al. 2010; Singaraja et al. 2014). These imply that higher $\mathrm{pCO}_{2}$ leads to higher bicarbonate concentrations in the groundwater, which in turn enhances the release of $\mathrm{F}^{-}$due to higher rock-water interactions under long residence time.
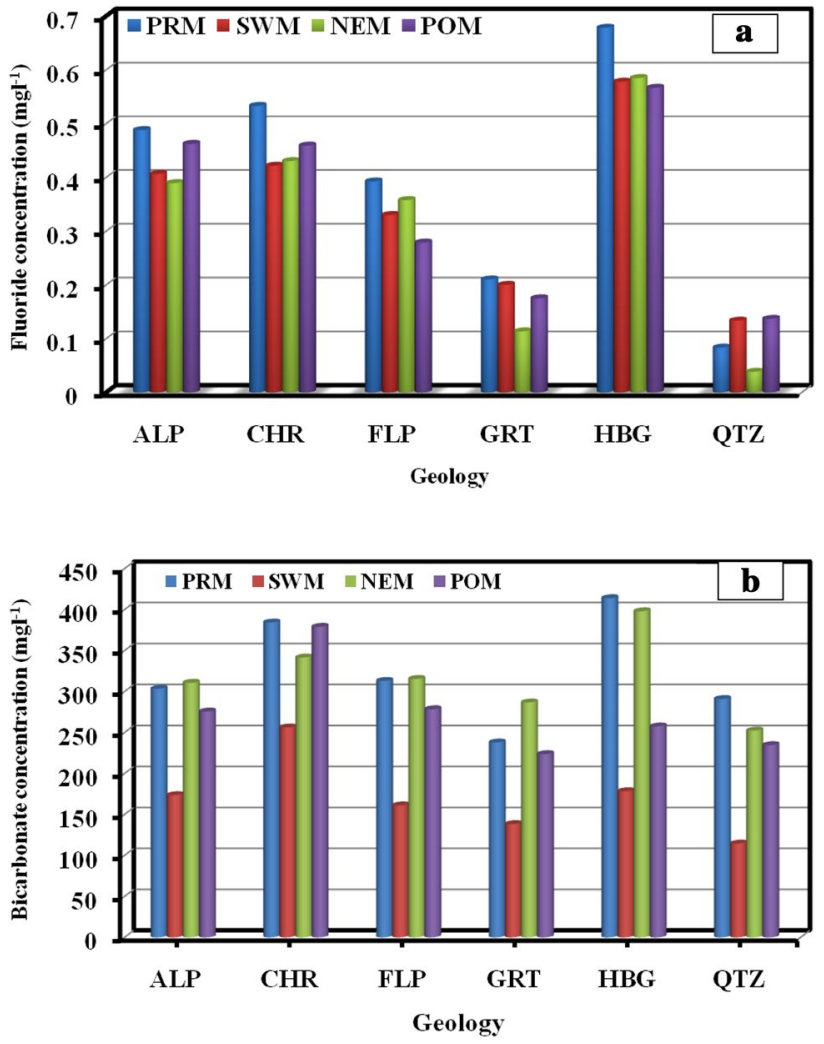

Fig. 9 a $\mathrm{F}^{-}$and $\mathbf{b} \mathrm{HCO}_{3}^{-}$versus geology for different seasons in the study area 

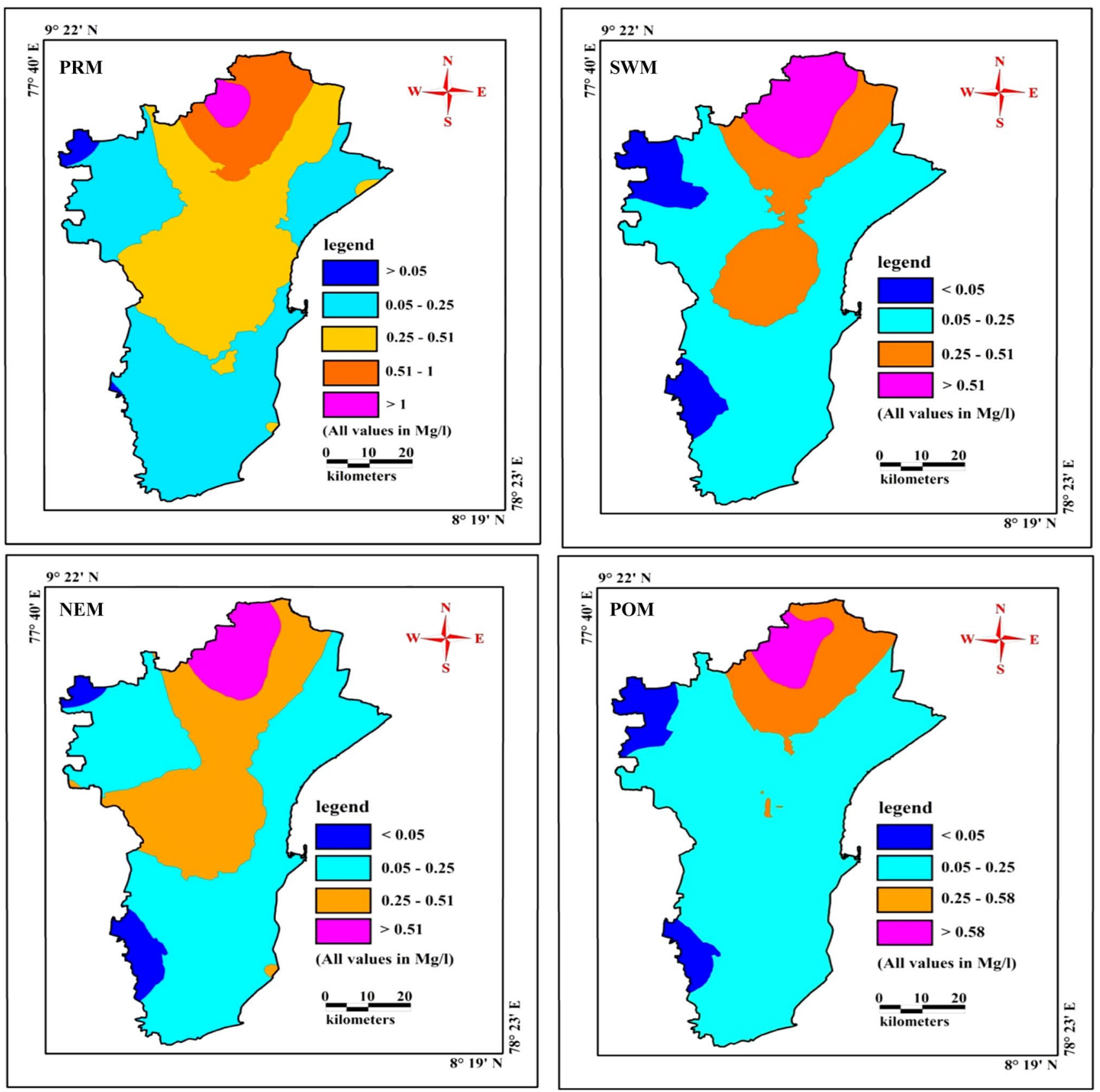

Fig. 10 Spatial distribution of $\mathrm{F}^{-}$during different seasons

\section{SI of carbonate minerals}

Saturation index for minerals such as magnesite $\left(\mathrm{MgCO}_{3}\right)$, aragonite $\left(\mathrm{CaCO}_{3}\right)$, calcite $\left(\mathrm{CaCO}_{3}\right)$, dolomite $\left(\mathrm{CaMg}\left(\mathrm{CO}_{3}\right)_{2}\right)$ were calculated. Saturation index of carbonate minerals are plotted against the concentration of $\mathrm{HCO}_{3}^{-}$ (in $\mathrm{mgl}^{-1}$ ) (Fig. 8). The saturation state of carbonate minerals are in the following orders: $\mathrm{SI}_{\mathrm{C}}>\mathrm{SI}_{\mathrm{A}}>\mathrm{SI}_{\mathrm{D}}>\mathrm{SI}_{\mathrm{M}}$ during PRM and NEM. $\mathrm{SI}_{\mathrm{D}}>\mathrm{SI}_{\mathrm{C}}>\mathrm{SI}_{\mathrm{D}}>\mathrm{SI}_{\mathrm{M}}$ during SWM and $\mathrm{SI}_{\mathrm{C}}>\mathrm{SI}_{\mathrm{D}}>\mathrm{SI}_{\mathrm{A}}>\mathrm{SI}_{\mathrm{M}}$ during POM season, respectively. SI of all carbonate minerals increases with increase in $\mathrm{HCO}_{3}^{-}$ during all seasons, due to increased groundwater recharge and subsequent dilution of chemical constituents present in groundwater. They form near saturation to saturation state. Excess of $\mathrm{HCO}_{3}^{-}$may result in stoichiometric dissolution of calcite and ion exchange (Gomez et al. 2006). A few samples show under saturation, which may be due to nonavailability of cations $\left(\mathrm{Ca}^{2+}\right.$ and $\left.\mathrm{Mg}^{2+}\right)$ which might have been removed from the aqueous system due to the process of cation exchange (McNab et al. 2009; Li et al. 2015). The 

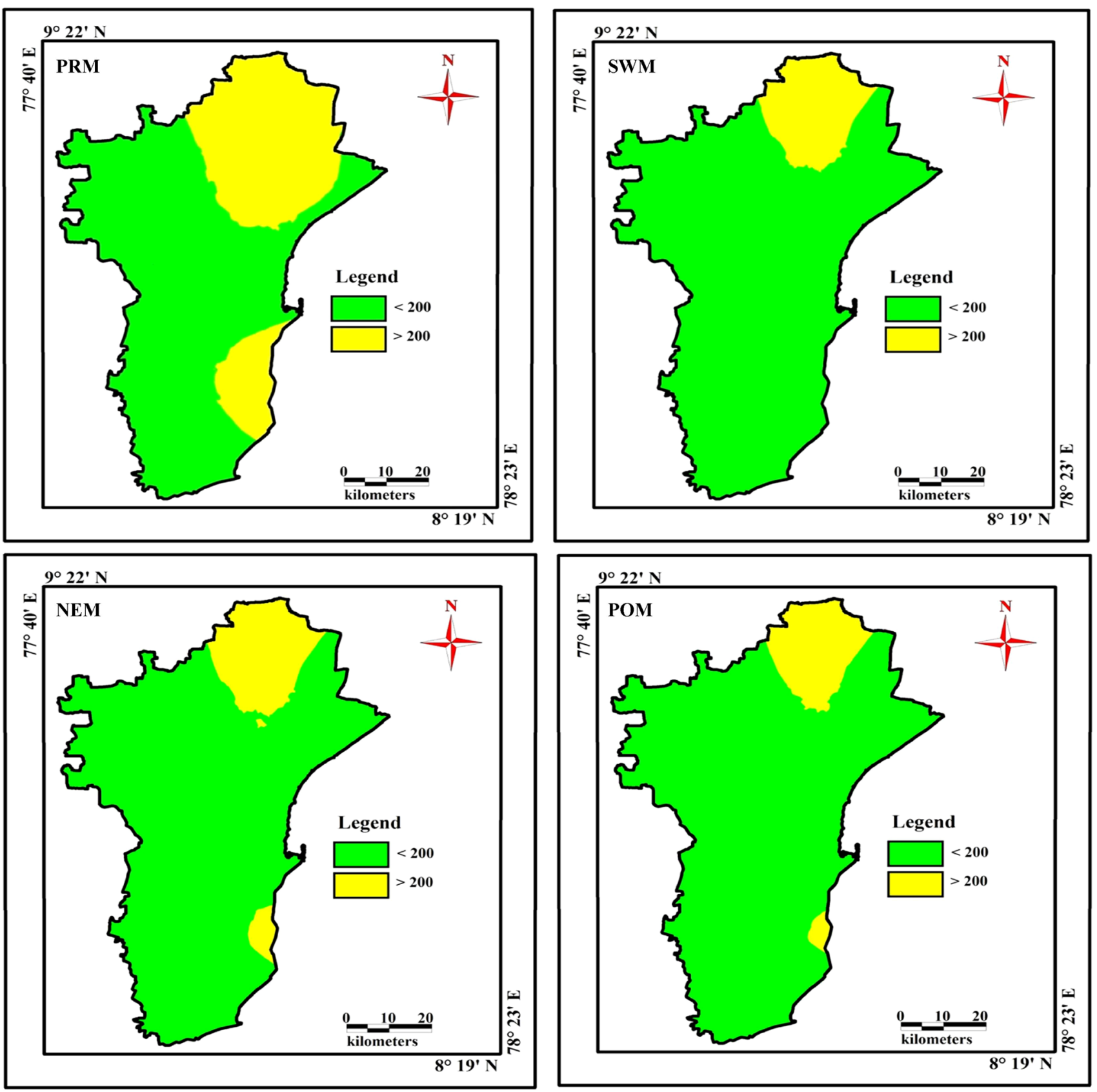

Fig. 11 Spatial distribution of $\mathrm{HCO}_{3}^{-}$during different seasons

carbonate minerals generally attain saturation when the concentration of $\mathrm{HCO}_{3}^{-}$reaches nearly $300 \mathrm{mgl}^{-1}$. It is interesting to note that the majority of samples attain saturation after this concentration, which may be due to the low flow conditions with high $\mathrm{pCO}_{2}$ value and extent of weathering by the parent material (Rosa Cidu and Luca Mereu 2007). It is also appealing to the order of dominance that are under saturation is $\mathrm{SI}_{\mathrm{Mg}}>\mathrm{SI}_{\mathrm{Do}}$ and $\mathrm{Si}_{\mathrm{C}}<\mathrm{SI}_{\mathrm{Ar}}$ but $\mathrm{SI}_{\mathrm{Mg}}<\mathrm{SI}_{\mathrm{Do}}$ and $\mathrm{Si}_{\mathrm{C}}>\mathrm{SI}_{\mathrm{Ar}}$ are the state of saturation. It may be due to the preferential addition of $\mathrm{Mg}$ to $\mathrm{CaCO}_{3}$ and formation of new
$\mathrm{Ca} \operatorname{Mg}\left(\mathrm{CO}_{3}\right)_{2}$, which results in the increase of $\mathrm{SI}_{\mathrm{Do}}$ in the saturation state than the other carbonate minerals. The saturation of magnesite requires $2 \mathrm{Mg}$ atoms to form an $\mathrm{MgCO}_{3}$ compound. So, the first available free magnesium tends to join with existing calcite to form dolomite or it forms new dolomite. It may due to overall precipitation reaction that proceeds as below (Davis et al. 1997).

$$
\text { 1. } \mathrm{CaCO}_{3}+\mathrm{Mg}^{2+} \rightarrow \mathrm{CaMg}\left(\mathrm{CO}_{3}\right)_{2}
$$




$$
\text { 2. } \mathrm{Ca}^{2+}+\mathrm{Mg}^{2+}+2 \mathrm{CO}_{3}^{2-} \rightarrow \mathrm{CaMg}\left(\mathrm{CO}_{3}\right)_{2}
$$

\section{Occurrence of high $\mathrm{F}^{-}$and $\mathrm{HCO}_{3}^{-}$groundwater}

The order of dominance of average fluoride concentration in various lithounits in all the seasons is as follows: hornblende biotite gneiss $>$ charnockite $>$ alluvial plain (river deposited) $>$ fluvial plain (coastal deposited) $>$ quartzite $>$ granite (Fig. 9). The bicarbonate dominance during all the seasons is as follows: hornblende biotite gneiss $>$ charnockite $>$ fluvial plain (coast deposited) $>$ alluvial plain (river deposited) $>$ quartzite $>$ granite (Fig. 9). Lithologically, the highest $\mathrm{F}^{-}$and $\mathrm{HCO}_{3}^{-}$contents in the groundwater occurred in the hornblende biotite gneiss areas of the study area. The spatial variations of the $\mathrm{F}^{-}$and $\mathrm{HCO}_{3}^{-}$concentrations are presented in Figs. 10 and 11. Physiographically, the highest $\mathrm{F}^{-}$and $\mathrm{HCO}_{3}^{-}$contents in groundwater occur in the northern part of the Tuticorin District due to HBG and charnockites geology (Manivannan et al. 2010; Manikandan et al. 2014). In the northern part of the Tuticorin District, the groundwater flow paths are longer and hence will have longer residence time and higher degree of rock-water interactions. This leads to higher concentrations of most of the elements in the groundwater including $\mathrm{F}^{-}$and $\mathrm{HCO}_{3}^{-}$. In other parts, the groundwater flow paths are comparatively shorter, residence time is lower and there is a less time of contact between water and minerals. It is also noted that $\mathrm{F}^{-}$and $\mathrm{HCO}_{3}^{-}$concentrations in alluvial and fluvial plain are typically low. But, higher concentrations of $\mathrm{F}^{-}$observed in these parts may be attributable to the mud, dust, industrial discharge, chemical fertilisers as well as the sources of clays, biotite and apatite at higher rate of evaporation (Subba Rao 2009). Significant $\mathrm{HCO}_{3}^{-}$concentrations are noted in the western and the eastern parts along the alluvial and fluvial region. The source of $\mathrm{HCO}_{3}^{-}$in noncalcareous aquifers are derived by two different processes, one is when $\mathrm{CO}_{2}$ mixes with water, it forms carbonic acid which decreases the $\mathrm{pH}$ of groundwater

$\mathrm{CO}_{2}+\mathrm{H}_{2} \mathrm{O} \leftrightarrow \mathrm{H}_{2} \mathrm{CO}_{3} \leftrightarrow \mathrm{HCO}_{3}^{-}$.

Second, the bicarbonate is derived when $\mathrm{CO}_{2}$ dissolves in water. This forms $\mathrm{HCO}_{3}^{-}$, which is a $\mathrm{pH}$ buffer. Hence, groundwater with high $\mathrm{HCO}_{3}^{-}$concentrations will have relatively high $\mathrm{pH}$

$\mathrm{CO}_{2}+\mathrm{H}_{2} \mathrm{O} \leftrightarrow \mathrm{H}_{2} \mathrm{CO}_{3} \leftrightarrow \mathrm{HCO}_{3}^{-}+\mathrm{H}^{+}$.

Also, it is noted that the spatial distribution of $\mathrm{HCO}_{3}^{-}$ coincides with that of $\mathrm{F}^{-}$concentration in the study area.

\section{Relationship in support of fluoride and bicarbonate concentration}

\section{Factor analysis}

Using factor analysis, four factors were taken for PRM, SWM and POM seasons and five factors for the NEM (Table 2). Liu et al. (2003) classified the absolute factor loadings values as $0.3-0.5$ (weak), $0.5-0.75$ (moderate) and $>0.75$ (strong), respectively. Fluoride concentration signifies as the third factor during PRM with 10.82 percentage of variance (PV). SWM results reveal that the second factor with $12.93 \mathrm{PV}$ is represented by $\mathrm{F}^{-}$. The $\mathrm{F}^{-}$factor is represented as the fourth factor with $9.38 \mathrm{PV}$ during NEM and again as second factor by $12.16 \mathrm{PV}$ during POM. High $\mathrm{F}^{-}$and $\mathrm{HCO}_{3}^{-}$groundwater at Tuticorin District displayed distinctive major ion chemistry. Generally, higher loading of $\mathrm{F}^{-}$and $\mathrm{HCO}_{3}^{-}$with relatively negative or low loading of other ions (Table 2), particularly $\mathrm{Ca}^{2+}, \mathrm{Mg}^{2+}, \mathrm{Na}^{2+}, \mathrm{K}^{2+}, \mathrm{pH}$ and $\mathrm{SO}_{4}^{2-}$ concentrations may be due to increasing weathering process with dissolution of fluorine-bearing minerals and the desorption of exchangeable $\mathrm{F}^{-}$from the loess. Long-term water-rock interactions may lead to the release of $\mathrm{F}^{-}$from fluorine-bearing minerals (Rafique et al. 2015; Gao et al. 2016a, b). In this area, hard rocks, such as HBG and charnockite, contained abundant fluorine-bearing minerals, including fluorite, biotite, hornblende and apatite (Singaraja et al. 2014). As one of the major fluorine-bearing natural minerals, fluorite dissolves rapidly under natural conditions (Fig. 5). Because the fluorine-bearing minerals are sparingly soluble, the presence of high $\mathrm{F}^{-}$concentrations in the groundwater require a long residence time, which is possible in the northern parts of Tuticorin District (Singaraja et al. 2015).

Table 2 Summary of fluoride represented factors during different periods of the study

\begin{tabular}{|c|c|c|c|c|}
\hline Seasons & PRM & SWM & NEM & POM \\
\hline Total number of factors & 4 & 4 & 5 & 4 \\
\hline Fluoride Factor & 3 & 2 & 4 & 2 \\
\hline $\mathrm{pH}$ & 0.17 & 0.29 & 0.10 & 0.04 \\
\hline $\mathrm{Ca}^{2+}$ & 0.02 & -0.06 & -0.01 & -0.08 \\
\hline $\mathrm{Mg}^{2+}$ & -0.01 & 0.04 & 0.06 & -0.05 \\
\hline $\mathrm{Na}^{+}$ & 0.02 & -0.09 & 0.00 & 0.08 \\
\hline $\mathrm{K}^{+}$ & 0.08 & 0.08 & -0.07 & -0.02 \\
\hline $\mathrm{Cl}^{-}$ & -0.02 & -0.09 & -0.06 & 0.00 \\
\hline $\mathrm{HCO}_{3}^{-}$ & 0.80 & 0.84 & 0.55 & 0.81 \\
\hline $\mathrm{NO}_{3}^{-}$ & -0.03 & -0.04 & -0.10 & 0.07 \\
\hline $\mathrm{PO}_{4}^{-}$ & 0.02 & 0.14 & -0.05 & -0.07 \\
\hline $\mathrm{F}^{-}$ & 0.85 & 0.80 & 0.92 & 0.81 \\
\hline $\mathrm{SO}_{4}^{2-}$ & 0.17 & 0.20 & 0.20 & 0.10 \\
\hline $\mathrm{H}_{4} \mathrm{SiO}_{4}$ & -0.06 & -0.06 & 0.08 & 0.22 \\
\hline
\end{tabular}



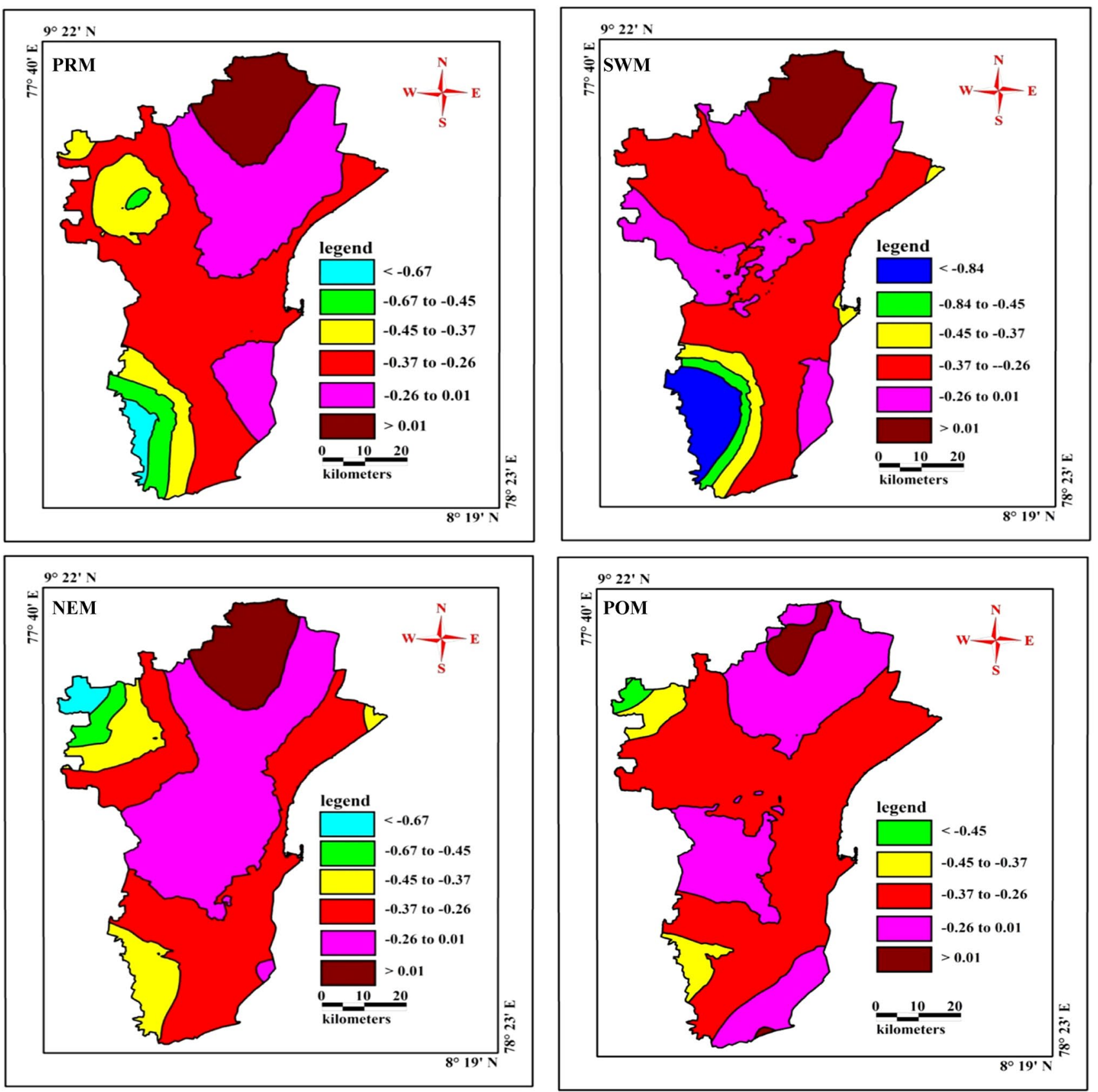

Fig. 12 Spatial distribution of $\mathrm{F}^{-}$and $\mathrm{HCO}_{3}^{-}$factor score during different seasons

Particularly, in all the seasons, $\mathrm{HCO}_{3}^{-}$is positively correlated with $\mathrm{F}^{-}$and higher factor scores are established in northern part of the study area suggesting that the minerals dissolve in the groundwater (Chidambaram et al. 2012; Singaraja et al. 2013). In addition, $\mathrm{pH}$ and $\mathrm{F}^{-}$is weak correlation as increase of alkalinity is attributable to the swell of bicarbonate ions, these ions control on $\mathrm{pH}$ values ,Hence, the alkalinity inversely relationship of the $\mathrm{pH}$ level during all the seasons (Subba Rao et al. 2003; Singaraja et al. 2014). $\mathrm{F}^{-}$and $\mathrm{HCO}_{3}^{-}$concentrations have negative loading with respect to calcite and lower $\mathrm{Ca}^{2+}$ concentrations allowed additional fluorite to dissolve, further increasing $\mathrm{F}^{-}$concentrations in groundwater. Hence, cation exchange promotes the release of $\mathrm{F}^{-}$from the groundwater at Tuticorin District (Singaraja et al. 2016). Agricultural activity is unlikely a major source of $\mathrm{F}^{-}$in the study area, given the insignificant correlation between $\mathrm{F}^{-}$and $\mathrm{NO}_{3}{ }^{-}$concentrations in groundwater (Chatterjee and Mohabey 1998; Singaraja et al. 2015). Figures 10 and 11 clearly indicate that elevated $\mathrm{HCO}_{3}^{-}$contents favoured $\mathrm{F}^{-}$release from the aquifer matrix into groundwater. Spatial distribution of $\mathrm{F}^{-}$and $\mathrm{HCO}_{3}^{-}$values 
corresponds to the hydrogeochemical active zone (Fig. 12) resulting from the factor scores, possibly due to the migration of these ions from the similar source.

\section{Conclusion}

The above study provides evidence on the major difference in the chemical composition of groundwater with respect to $\mathrm{F}^{-}$and $\mathrm{HCO}_{3}^{-}$concentration during all the seasons. Higher $\mathrm{F}^{-}$and $\mathrm{HCO}_{3}^{-}$are noted in PRM, followed by NEM, SWM and low levels in POM, which is as a result of dilution effect after monsoon periods. It is also interesting to note that $\mathrm{pCO}_{2}$ increases with $\mathrm{HCO}_{3}^{-}$, due to longer residence time and the dissolution of minerals from the host rocks. Majority of the PRM, POM and NEM samples show evidence of higher $\mathrm{pCO}_{2}$ values and $\log \mathrm{pCO}_{2}$ values linearly decrease with $\mathrm{pH}$. Higher $\mathrm{pH}$ shows lesser $\mathrm{pCO}_{2}$, which is more significant during SWM seasons, indicating fresh water recharge or less atmosphere interaction. The spatial distribution of $\mathrm{F}^{-}$and $\mathrm{HCO}_{3}^{-}$signify that the higher concentrations are seen along the hornblende biotite gneiss and charnockite rocks which lies in the northern part of the region indicating lithological control in the distribution of fluorides and bicarbonates during all the seasons. The $\mathrm{F}^{-}$concentration in groundwater is controlled by degree of weathering, longer flow paths, higher residence time and more time of contact between water and minerals in the study area. The source of $\mathrm{HCO}_{3}^{-}$in groundwater is due to mixing of $\mathrm{CO}_{2}$ with groundwater forming carbonic acid which decreases the $\mathrm{pH}$ of groundwater and bicarbonate is derived when $\mathrm{CO}_{2}$ dissolves in water forming $\mathrm{HCO}_{3}^{-}$in relatively high $\mathrm{pH}$ condition. Fluoride shows a positive correlation with $\mathrm{HCO}_{3}^{-}$, but poor correlation with $\mathrm{pH}, \mathrm{Ca}^{2+}$ and $\mathrm{Mg}^{2+}$ during all seasons. It is attractive to note that increase of bicarbonate ions control the $\mathrm{pH}$ level in groundwater, and consequently the increase in alkalinity with low $\mathrm{pH}$ and $\mathrm{Ca}^{2+}$ levels due to cation exchange promotes the release of $\mathrm{F}^{-}$. Poor correlation between $\mathrm{F}^{-}$and $\mathrm{NO}_{3}^{-}$concentrations indicate agricultural activity as an unlikely source of $\mathrm{F}^{-}$in groundwater in the study area. Spatial distribution of $\mathrm{F}^{-}$and $\mathrm{HCO}_{3}^{-}$values corresponds to the hydrogeochemical active zone resulting from the factor scores, possibly due to the migration of these ions from the similar source. Since most of the groundwater is having high $\mathrm{F}^{-}$concentration, it is recommended that regular groundwater monitoring and integrated management should be established for the safe public water supply in the study area.

Acknowledgements The author Dr. CSR would like to acknowledge the funding agency Department of Science and Technology, India, under WAR for water, (DST/WAR-W/WSI/06/2010 dated 25.02.2011) for sampling and analysis. The authors are grateful to the anonymous referees for their constructive comments and suggestions, which led to significant improvements to the manuscript. Special thanks to Enrico Drioli (editor-in-chief) for fine tuning the manuscript.
Open Access This article is distributed under the terms of the Creative Commons Attribution 4.0 International License (http://creativeco mmons.org/licenses/by/4.0/), which permits unrestricted use, distribution, and reproduction in any medium, provided you give appropriate credit to the original author(s) and the source, provide a link to the Creative Commons license, and indicate if changes were made.

\section{References}

Ayoob S, Gupta AK (2006) Fluoride in drinking water: a review on the status and stress effects. Crit Rev Environ Sci Technol 36:433-487

Brindha K, Rajesh R, Murugan R, Elango L (2012) Fluoride contamination in groundwater in parts of Nalgonda district Andhra Pradesh India. Environ Monit Assess 172:481-492

Central Ground Water Board (2009) South Eastern Coastal Region. District Groundwater Brochure, Thoothukudi district, Tamil Nadu

Chae GT, Yun ST, Kim K, Mayer B (2006) Hydrogeochemistry of sodium-bicarbonate type bedrock groundwater in the Pocheon spa area, South Korea. J Hydrol 321:326-343

Chae GT, Yun ST, Bernhard M, Kim KH, Kim SY, Kwon JS (2007) Fluorine geochemistry in bedrock groundwater of South Korea. Sci Total Environ 385(1):272-283

Chandrasekharan H, Gupta N, Navada SV (1997) Deuterium and oxygen-18 isotopes on groundwater salinization of adjoining salt pans in Porbandar coast, Gujarat, India, Hydrochemistry (Proceedings of the Rabat Symposium) IAHS Publ. no. 244

Chatterjee MK, Mohabey NK (1998) Potential fluorosis problems around Chandidongri, Madhya Pradesh, India. Environ Geochem Health 20:1-4

Chidambaram S, Bala Krishna Prasad M, Manivannan R, Karmegam U, Singaraja C, Anandhan P, Prasanna MV, Manikandan S (2012) Environmental hydrogeochemistry and genesis of fluoride in groundwaters of Dindigul district. Environ Earth Sci. https://doi.org/10.1007/s12665-012-1741-9

Chidambaram S, Prasanna MV, Singaraja C, Thilagavathi R, Pethaperumal S, Tirumalesh K (2013) Study on the saturation index of the carbonates in the groundwater using WATEQ4F, in layered coastal aquifers of Pondicherry. J Geol Soc India 80:813-824

Codling G, Vogt A, Jones PD, Wang TY, Wang P, Lu YL, Corcoran M, Bonina S, Li A, Sturchio NC, Rockne KJ, Ji K, Khim JS, Naile JE, Giesy JP (2014) Historical trends of inorganic and organic fluorine in sediments of LakeMichigan. Chemosphere 114:203-209

Davis EE, Fisher AT, Firth JV (1997) Proc. ODP, Init. Repts. 168: College Station, TX (Ocean Drilling Program)

Edmunds WM, Smedley P (2005) Fluoride in natural waters. In: Selinus O, Alloway B, Centeno JA, Finkelman RB, Fuge R, Lindh U, Smedley P (eds) Essentials of medical geology. Elsevier, Amsterdam, pp 301-329

Edmunds WM, Smedley PL (2013) Fluoride in natural waters. Essentials of medical geology, pp 311-336

Gao XB, Wang YX, Hu QH (2011) Effects of anion competitive adsorption on arsenic enrichment in groundwater. J Environ Sci Health Part A 46(5):471-479

Gao X, Hu Y, Li C, Dai C, Li L, Ou X, Wang Y (2016a) Evaluation of fluorine release from air deposited coal spoil piles: a case study at Yangquan city, northern China. Sci Total Environ 545-546:1-10

Gao X, Hu Y, Li C, Dai C, Li L, Ou X, Wang Y (2016b) Evaluation of fluorine release from air deposited coal spoil piles: a case study at Yangquan city, Northern China. Sci Total Environ 545-546:1-10

Gibbs RJ (1970) Mechanisms controlling world water chemistry. Science 170:1088-1090

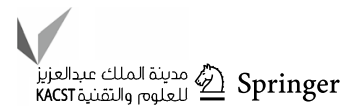


Gomez P, Turrero MJ, Garralón A, Peña J, Buil B, de la Cruz B, Sánchez M, Sánchez DM, Quejido A, Bajos C, Sánchez L (2006) Hydrogeochemical characteristics of deep groundwaters of the Hesperian Massif (Spain). J Iber Geol 32(1):113-131

Guo Q, Wang Y, Ma T, Ma R (2007) Geochemical processes controlling the elevated fluoride concentrations in groundwaters of the Taiyuan Basin, Northern China. J Geochem Explor 93:1-12

Hammarstrom JM, Seal RR II, Meier AL, Kornfeld JM (2005) Secondary sulfate minerals associated with acid drainage in the eastern US: recycling of metals and acidity in surficial environments. Geochemistry of Sulfate Minerals: A Tribute to Robert O. Rye. Paper 2. http://digitalcommons.unl.edu/usgsrye/2

Hem JD (1985) Study and interpretation of the chemical characteristics of natural water. USGS Water Supply Paper 2254:117-120

Jacks G, Bhattacharya P, Chaudhary V, Singh KP (2005) Controls on the genesis of some high fluoride groundwaters in India. Appl Geochem 20(2):221-228

Li Z, Tainosho Y, Shiraishi K, Owada M (2003) Chemical characteristics of fluorine-bearing biotite of early Paleozoic plutonic rocks from the Sor Rondane Mountains, East Antarctica. Geochem $\mathrm{J} 37: 145-161$

Li C, Gao X, Wang Y (2015) Hydrogeochemistry of high-fluoride groundwater at Yuncheng Basin, northern China. Sci Total Environ 508:155-165

Manikandan S, Chidambaram S, Ramanathan AL, Prasanna MV, Karmegam U, Singaraja C, Paramaguru P, Jainab I (2014) A study on the high fluoride concentration in the magnesium-rich waters of hard rock aquifer in Krishnagiri district, Tamil Nadu, India. Arab J Geosci 7(1):273-285

Manivannan R, Chidambaram S, Anandhan P, Karmegam U, Singaraja C, Johnson Babu G, Prasanna MV (2010) Study on the significance of temporal ion chemistry in groundwater of Dindigul District, Tamil Nadu, India. E-J Chem 8(2):938-944

McNab JWW, Singleton MJ, Moran JE, Esser BK (2009) Ion exchange and trace element surface complexation reactions associated with applied recharge of low-TDS water in the San Joaquin Valley. Calif Appl Geochem 24(1):129-137

Mondal NC, Singh VS (2004) A new approach to delineate the groundwater recharge zone in hard rock terrain. J Geol Soc India 87(5):658-662

Naseem S, Rafique T, Bashir E, Bhanger MI, Laghari A, Usmani TH (2010) Lithological influences on occurrence of high-fluoride groundwater in Nagar Parkar area, Thar Desert, Pakistan. Chemosphere 78:1313-1321

Prasanna MV, Chidambaram S, Shahul Hameed A, Srinivasamoorthy K (2010) Study of evaluation of groundwater in Gadilam basin using hydrogeochemical and isotope data. Environ Monit Assess 168:63-90

Rafique T, Naseem S, Ozsvath D, Hussain R, Bhanger MI, Usmani TH (2015) Geochemical controls of high fluoride groundwater in Umarkot Sub-District, Thar Desert, Pakistan. Sci Total Environ 530-531:271-278

Rosa Cidu and Luca Mereu (2007) The Abandoned Copper-Mine of Funtana Raminosa (Sardinia): Preliminary evaluation of its impact on the aquatic system. IMWA Symposium 2007: Water in Mining Environments, R.Cidu \& F. Frau (Eds), 27th-31st May, Cagliari, Italy

Selvam S, Venkatramanan S, Chung SY, Singaraja C (2016) Identification of groundwater contamination sources in Dindigul district of Tamil Nadu, India using GIS and multivariate statistical analyses. Arab J Geosci 9(5):1-14

Singaraja C, Chidambaram S, Anandhan P, Prasanna MV, Thivya C, Thilagavathi R (2012) A study on the status of fluoride ion in groundwater of coastal hard rock aquifers of South India. Arab J Geosci 6:4167-4177
Singaraja C, Chidambaram S, Anandhan P, Prasanna MV, Thivya C, Thilagavathi R (2013) A study on the status of fluoride ion in groundwater of coastal hard rock aquifers of south India. Arab J Geosci 6(11):4167-4177

Singaraja C, Chidambaram S, Anandhan P, Prasanna MV, Thivya C, Thilagavathi R, Sarathidasan J (2014) Geochemical evaluation of fluoride contamination of groundwater in the Thoothukudi District of Tamil Nadu, India. Appl Water Sci 4(3):241-250

Singaraja C, Chidambaram S, Anandhan P, Prasanna MV, Thivya C, Thilagavathi R (2015) A study on the status of saltwater intrusion in the coastal hard rock aquifer of South India. Environ Dev Sustain 17(3):443-475

Singaraja C, Chidambaram S, Jacob Noble, Ezhilarasan E, Velmurugan C, Manikandan M, Rajamani S (2016) Taxonomy of groundwater quality using multivariate and spatial analyses in the Tuticorin District, Tamil Nadu, India. Environ Dev Sustain 18(2):393-429

Srinivasamoorthy K, Chidambaram S, Prasanna MV, Vasanthavigar M, John Peter A, Anandhan P (2008) Identification of major sources controlling groundwater chemistry from a hard rock terrain-a case study from Mettur Taluk, Salem district, Tamil Nadu, India. J Earth Syst Sci 117(1):49-58

Srinivasamoorthy K, Nandha Kumar C, Vasanthavigar M, Vijayaraghavan K, Rajiv Gandhi R, Chidambaram S, Anandhan P, Manivannan R, Vasudevan S (2009) Groundwater quality assessment from a hard rock terrain, Salem District of Tamil Nadu, India. Arab J Geo Sci 4:91-102

Subba Rao N (2003) Groundwater quality: focus on fluoride concentration in rural parts of Guntur districts, Andhra Pradesh, India. Hydrol Sci J 48(5):835-847

Subba Rao N (2009) Fluoride in groundwater, Varaha River Basin, Visakhapatnam District, Andhra Pradesh, India. Environ Monit Assess 152:47-60

Subba Rao N, Surya Rao P, Venktram Reddy G, Nagamani M, Vidyasagar G, Satyanarayana NLVV (2012) Chemical characteristics of groundwater and assessment of groundwater quality in Varaha River Basin, Visakhapatnam District, Andhra Pradesh, India. Environ Monit Assess 184:5189-5214

Subba Rao N, Dinakar A, Surya Rao P, Rao PN, Madhnure Pandith, Prasad KM, Sudarshan G (2016) Geochemical processes controlling fluoride-bearing groundwater in the granitic aquifer of a semiarid region. J Geol Soc India 88:350-356

Thilagavathi R, Chidambaram S, Thivya C, Prasanna MV, Singaraja C, Tirumalesh K, Pethaperumal S (2014) Delineation of natural and anthropogenic process controlling hydrogeochemistry of layered aquifer sequence. Proc Natl Acad Sci USA 88(1):95-108

Thivya C, Chidambaram S, Singaraja C, Thilagavathi R, Prasanna MV, Jainab I (2013) A study on the significance of lithology in groundwater quality of Madurai district, Tamil Nadu (India). Environ Dev Sustain 15:1365-1387

Thivya C, Chidambaram S, Thilagavathi R, Prasanna MV, Singaraja C, Adithya VS, Nepolian M (2015) A multivariate statistical approach to identify the spatio-temporal variation of geochemical process in a hard rock aquifer. Environ Monit Assess 187(9):4738

Venkatramanan S, Chung SY, Ramkumar T, Gnanachandrasamy G, Vasudevan S (2013) A multivariate statistical approach on physicochemical characteristics of groundwater in and around Nagapattinam district, Cauvery deltaic region of Tamil Nadu, India. Earth Sci Res J 17:97-103

WHO (2004) Fluoride in drinking water-background document for development of WHO guidelines for drinking water quality. WHO, Geneva, p 515

Publisher's Note Springer Nature remains neutral with regard to jurisdictional claims in published maps and institutional affiliations. 